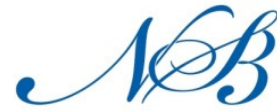

Notulae Scientia Biologicae

\title{
Ohmic Treatment of Pear Purées (cv. 'Conference') in Terms of Some Quality Related Attributes
}

\author{
Oana-Viorela NISTOR, Aida VASILE, Doina G. ANDRONOIU, Gabriel D. \\ MOCANU, Elisabeta BOTEZ, Nicoleta STĂNCIUC*
}

"DunăreadeJos"University of Galați, Faculty of Food Science and Engineering,DomneascäStreet 111, 800201, Galați, România; nsava@ugal.ro("corresponding author)

\begin{abstract}
The effect of ohmic treatment on some quality related characteristics of pear purée (cv. 'Conference') such as color, reducing sugars, total phenols, rheological behavior and microbial counts, was analyzed. The inactivation kinetics of pectin methyl esterase (PME) in pear crude extract and purée were studied by conventional thermal and ohmic treatments. Thermal inactivation of PME in crude extract was described by a first-order kinetic model. The activation energy values suggested the presence of two isoenzymes with different thermostability. The ohmic heating reduced PME activity by $96 \%$ at $25 \mathrm{~V} \cdot \mathrm{cm}^{-1}$. Minimal changes induced by ohmic heating on above quality related aspects were observed. Supporting this statement, there were no significant changes in the nutritional and sensorial attributes. It was reported an increase of $3 \%$ of reducing sugar content for the ohmic heated samples. The phenolic content of the treated samples registered a reduction of $59 \%$ in comparison with fresh pear purée. The pear purée presented a non-Newtonian pseudoplastic behaviour. The Ostwald de Waele model was fitted to rheograms and the consistency coefficient $(m)$ and flow behavior index $(n)$ were determined. Results obtained for the microbial charge were higher in the control samples. Thus, microbial counts showed complete inactivation of yeast and mold at voltage gradient higher than $17.5 \mathrm{~V} \cdot \mathrm{cm}^{-1}$.
\end{abstract}

Keywords: minimal processing, pear purée, pectin methylesterase, rheological behavior

\section{Introduction}

During processing of plant-based food products the aim is to guarantee food safety and quality traits among which texture forms one of the most prominent quality attributes. Therefore, texture is an important quality factor in both fresh and processed fruits. During ripening, structural changes in the middle lamella and primary cell walls occur, leading to the cell separation and softening of tissue (Barrett et al., 1994). Several enzymes are responsible for these structural changes, such as polygalacturonase, pectin methyl esterase, $\beta$-galactosidase, cellulose etc.

Pectin methylesterase (EC 3.1.1.11) (PME) is an enzyme that acts mainly in the hydrolysis of methyl ester groups in pectin chains to form carboxylate groups, releasing methanol and $\mathrm{H}_{3} \mathrm{O}^{+}$ (Jayani et al., 2005). Pectin greatly influences the textural properties of the plant cell wall and thus the textural properties of plant-based food products (Vandevenne, 2011). PME inactivation should be achieved without compromising other quality or safety aspects (Hendrix et al., 1995). Current inactivation of PME is accomplished by heat (Chen et al., 1993) however, conventional thermal treatments cause adverse effects such as color alterations, flavor changes, bioactive compounds loss and nutritional value reduction (Giner et al., 2001). Thus, inactivation of PME by alternative methods becomes a matter of interest, to avoid quality degradation of fruits or vegetables based products by thermal processing (Elez-Martínez et al., 2007).

Ohmic treatment of food products involves the passage of alternating current, thus generating internal heat as a result of electrical resistance (Reznick, 1996). The amount of heat generated inside of food is directly related to the current induced by the voltage gradient in the field and the electrical conductivity (Sastry et al., 1996). The main advantage of this technology consists in rapid and uniform heating, resulting in less thermal damage to the product (Sastry et al., 2000). In addition, the absence of a hot surface reduces fouling problems. Although the technology of ohmic heating appears to be promising and highly effective, there is little information concerning the effects of this technique on specific food products compared to conventional pasteurization.

The objectives of this study was to evaluate the influence of ohmic treatment on pear purée in relation with some quality characteristics such as color, reducing sugars, total phenols, rheological behavior and microbial counts. As the development of an adequate ohmic processing requires information about the behavior and kinetic data of enzymes in order to achieve enzymatically stable products without over processing, inactivation kinetics of PME in crude extract and pear purée were studied by conventional thermal and respectively ohmic treatments. 


\section{Materials and methods}

\section{Materials}

Pear fruit of Conference variety were purchased at commercial maturity during the year 2012 by a local producer (Galati, Romania). Apple pectin (75\% degree of esterification) was obtained from Sigma-Aldrich Chemie GmbH Germany. All chemicals were of analytical grade.

\section{Methods \\ PME extraction}

The extraction of PME was performed according to the method of Ly-Nguyen et al. (2002). A portion of $1.0 \mathrm{~kg}$ of pear was homogenized with the addition of $500 \mathrm{~mL}$ of distilled water. The suspension was filtered using cheesecloth. The supernatant was discarded and the pellet was washed twice with $500 \mathrm{~mL}$ distillated water to remove other organic and color compounds. Then the pellet was mixed overnight in a $0.2 \mathrm{M}$ Tris (hydroxylmethyl-amino-methane) buffer (Tris buffer) containing $1 \mathrm{M}$ $\mathrm{NaCl}, \mathrm{pH} 8.0$ (1:1 w/v). After extraction, the suspension was filtered using cheesecloth and the pellet was discarded. As a result, the pear salt PME extract was obtained. Salt PME extracts were partially purified by ammonium sulphate precipitation at 30\% saturation. After stirring for $30 \mathrm{~min}$ and centrifugation at 18,000 $\mathrm{g}$ for $15 \mathrm{~min}$, the pellets were discarded. The supernatants were precipitated again by ammonium sulphate up to $80 \%$ saturation for $30 \mathrm{~min}$. The precipitates containing PME were collected by centrifugation at $18,000 \mathrm{~g}$ for $15 \mathrm{~min}$. These precipitates were dissolved in $20 \mathrm{mM}$ citrate buffer ( $\mathrm{pH} 7.0$ ), using $5 \mathrm{~mL}$ of buffer per $100 \mathrm{~g}$ of fresh material, to obtain the crude extracts.

\section{Pectin methylesterase activity}

Pectin methylesterase (PME) activity was determined by a $\mathrm{pH}$ stat titration (Titrino, Metrohm, Switzerland) of the acid produced with a mixture consisting of $500 \mu \mathrm{L}$ of crude enzyme extract in $20 \mathrm{mM}$ citrate buffer for the thermal inactivation experiments and $5 \mathrm{~g}$ of un-treated samples for the ohmic treatment studies, $30 \mathrm{~mL}$ of $3.5 \mathrm{mg} \cdot \mathrm{mL}^{-1}$ apple pectin solution containing $0.117 \mathrm{M} \mathrm{NaCl}$ at $\mathrm{pH} 7.0$ and $25^{\circ} \mathrm{C}$. The PME activity unit is defined as the amount of enzyme required to release $1 \mu \mathrm{mol}$ of acid per minute, under the above mentioned assay conditions.

\section{Thermal inactivation kinetics}

Kinetic parameter values for thermal inactivation of PME were determined on the basis of isothermal inactivation experiments and determination of the remaining activity of heattreated samples. The experiments of PME were conducted using the test tube method. Aliquots $(0.200 \mathrm{~mL})$ of enzyme solutions were placed in test tubes and immersed in a water bath (Digibath-2 BAD 4, RaypaTrade, Barcelona, Spain) at temperatures ranging between $50{ }^{\circ} \mathrm{C}$ and $80{ }^{\circ} \mathrm{C}$ for different holding times (0-35 min). After thermal treatment, the test tubes were immediately immersed in ice water to allow rapid cooling.

\section{Puréespreparation}

The fruit were peeled and the seeds were removed. The purées $(1.0 \mathrm{~kg}$ of fruit) were prepared by grinding the pulp with a blender. Fresh fruit purées were immediately analyzed. Three experimental samples were obtained for un-treated and ohmic treated purée samples. The $\mathrm{pH}$ was controlled with a Mettler
Toledo $\mathrm{pH}$ meter. The physico-chemical values of fresh pear purée were $\mathrm{pH} 3.7$, the titrable acidity at $9.0 \mathrm{~g}$ malic acid per $1,000 \mathrm{~g}$ and dry matter value $11.3 \%$.

\section{Obmic treatment of fruit purées}

Discontinuous ohmic treatment equipment, consisting of a power supply of $10 \mathrm{~kW}$, an ohmic heating cell (a thermoresistant tank, two stainless steel electrodes of $5 \mathrm{~mm}$ diameter placed at an equal distance of $10 \mathrm{~cm}$ ) was used. Temperatures were monitored using a thermocouple, placed at the geometrical centre of the cell. Voltage and current intensity were measured with a voltmeter, respectively an ampermeter. For PME inactivation kinetics, the samples were treated using an alternative current source of $50 \mathrm{~Hz}$, with voltage gradients ranging from $15 \mathrm{~V} \cdot \mathrm{cm}^{-1}$ to $25 \mathrm{~V} \cdot \mathrm{cm}^{-1}$. For each value of the voltage gradients, the temperature was maintained for 3 minutes by covering the sample with aluminum foil, while the temperature of the samples was measured with a thermocouple. The changes in quality related parameters were measured by using a voltage gradient of $25 \mathrm{~V} \cdot \mathrm{cm}^{-1}$ for 3 minutes.

\section{Color analysis}

Pear purée color was measured using a tristimulus colorimeter (Model AA200, Zetalab, Milano, Italy). Samples of $10 \mathrm{~g}$ were placed in a cell and measured for $L, a$, and $b$ values. An increasing $L$ value represented an increase in lightness $(L=$ 0 , dark; $L=100$, light). An increase in $a$ value indicated an increase in redness $(-a=$ green, $+a=$ red $)$. Three measurements were taken on each sample and values were averaged. Browning index and color changes $(\Delta \mathrm{E})$ were calculated as described by Hutchings (1994).

\section{Reducing sugar analysis}

The concentration of reducing sugar was determined by using 3, 5-dinitrosalycilic acid (DNS) reagent with small changes (Miller, 1959). The filtrate was centrifuged at 4,500 rpm for 10 minutes and the supernatant was collected. DNS reagent was prepared by mixing $40 \mathrm{~mL}$ water with $1 \mathrm{~g}$ of DNS and $2 \mathrm{~mL}$ of $50 \% \mathrm{NaOH} .30 \mathrm{~g}$ Rochelle salt (potassium sodium tartrate) was added to the mixture. The reducing sugar was measured as follows: $3 \mathrm{~mL}$ of DNS reagent was added to 1 $\mathrm{mL}$ sample, the mixture was boiled for $5 \mathrm{~min}$, cooled and the reduced sugar concentration was measured at $540 \mathrm{~nm}$ wavelength using a Lambda $25 \mathrm{UV} / \mathrm{V}$ is Spectrometer (Perkin Elmer, Beaconsfield, UK) with $1 \mathrm{~cm}$ glass cells. Calibration standard solutions with concentrations in the range of $0.2-1.2$ $\mathrm{mg} \mathrm{mL}^{-1}$ were prepared by diluting the stock solution of glucose with water.

\section{Totalphenolic content}

The total phenolic content was measured using a modified colorimetric Folin-Ciocalteu method (Budini et al., 1980). Briefly, a volume of $2.5 \mathrm{~mL}$ of deionized water and $100 \mathrm{~mL}$ of a known dilution of the sample were added to a $10 \mathrm{~mL}$ volumetric flask. Folin-Ciocalteu reagent $(0.5 \mathrm{~mL})$ was added to the solution and allowed to react for $5 \mathrm{~min}$. Then, $1.5 \mathrm{~mL}$ aliquots of $20 \%$ sodium carbonate solution were added and the mixture was made up to $10 \mathrm{~mL}$ with deionized water. The color developed over $120 \mathrm{~min}$, and the absorbance was read at 765 nm using a Hewlett-Packard spectrophotometer HP 
234

8452A (Cheadle Heath, Stockport Cheshire, UK). The measurements were compared to a standard curve of gallic acid and expressed as mg gallic acid equivalent $100 \mathrm{~g}^{-1}$ fresh matter (mg GAE $\left.100 \mathrm{~g}^{-1} \mathrm{FM}\right)$.

\section{Rheologicalmeasurements}

The rheological measurements were made with the rotational viscometer Brookfield DV-E equipped with a LV2 (Liquid viscosity) (Brookfield Viscometers Ltd, Harlow, UK). The apparent viscosity, $\eta$, is defined as the ratio of shear stress, $\tau$, to the shear rate, $\gamma$, $(\eta=\tau / \gamma)$. The LV2 spindle characteristics were: diameter 18.72 $\mathrm{mm}$ and height $115 \mathrm{~mm}$.

The shear rate $\left(\gamma, s^{-1}\right)$ was calculated using the eq. 1 :

$$
\gamma=0.212 \cdot N, s^{-1}
$$

where: 0.212 - is a spindle constant and $\mathrm{N}$ is the rotor speed in rot.min ${ }^{-1}$.

The temperature of this system was kept constant at $21^{\circ} \mathrm{C}$ through a liquid thermal circulator. In order to investigate the reproducibility of the results, three experimental runs were accomplished for each product, and the resulting shear stress values were averaged.

\section{Microbial counts}

Microbial counts followed the standard ISO 7218-1996 "Microbiology of food and animal feeding stuffs general rules for microbiological examinations" methods.

\section{Kinetic data analysis} (Eq.2):

PME inactivation was described by the first-order kinetic model

$$
\ln \left(A t / A_{0}\right)=-k t
$$

where $A_{0}$ and $A_{t}$ are the initial activity and the remaining activity at time $t$, respectively.

The relation presented in eq. 2 is valid under isothermal condition, thereby the inactivation rate constant, $k$, can be determined from a linear regression of $\ln \left(A t / A_{0}\right)$ versus heating time.

The temperature dependence of the inactivation rate constants was estimated using the Arrhenius model (Eq.3):

$$
\ln k=\ln k_{0}-\mathrm{E}_{\mathrm{a}} / \mathrm{RT}
$$

where $T$ is the absolute temperature $(\mathrm{K}), k_{0}$ is the rate constant at reference temperature $\left(T_{0}\right), E_{a}$ is the activation energy $\left(\mathrm{J} \cdot \mathrm{mol}^{-1}\right)$ and $R$ is the universal gas constant $\left(8.314 \mathrm{~J} \cdot \mathrm{mol}^{-1} \cdot \mathrm{K}^{-1}\right)$. The activation energy and standard deviation values were estimated using linear regression on Eq. (3).

\section{Statistical analysis}

All experiments were performed in triplicates, and the results were expressed as the average of resulting data. Statistical and data analysis were conducted with data analysis tool pack of the Microsoft Excel software.

\section{Results and discussions}

\section{Thermal inactivation kinetics of crude pear PME extract}

Isothermal inactivation of crude PME extract dissolved in 20 $\mathrm{mM}$ citrate buffer ( $\mathrm{pH} 7.0$ ) could be accurately described by a first order model in a temperature range of $50-80^{\circ} \mathrm{C}$ (Fig. 1).
Table 1. Estimated kinetic parameters ( $D$-values and $z$, rate constant $k$ and activation energy $E a$ ) of PME inactivation in 0.01 Tris buffer at $\mathrm{pH} 7.0$

\begin{tabular}{lcc}
\hline Temperature $\left({ }^{\circ} \mathrm{C}\right)$ & $D$ values $(\mathrm{min})$ & $k\left(\mathrm{~min}^{-1}\right) \times 10^{2}$ \\
\hline 50 & $307.06 \pm 3.30^{\circ}$ & $0.75 \pm 0.08$ \\
55 & $230.30 \pm 3.93$ & $1.00 \pm 0.34$ \\
60 & $132.35 \pm 1.64$ & $1.74 \pm 0.23$ \\
65 & $84.98 \pm 1.05$ & $2.71 \pm 0.64$ \\
70 & $51.40 \pm 0.95$ & $4.48 \pm 0.49$ \\
75 & $19.27 \pm 0.72$ & $11.95 \pm 1.25$ \\
80 & $8.25 \pm 0.96$ & $27.91 \pm 2.13$ \\
$z$-values $\left({ }^{\circ} \mathrm{C}\right)$ & $19.23 \pm 1.23^{\circ} \mathrm{C}\left(R^{2}=0.97\right)$ & \\
$E a\left(\mathrm{~kJ} \cdot \mathrm{mol}^{-1}\right)$ & & $112.95 \pm 10.60\left(R^{2}=0.96\right)$ \\
\hline standard errors & &
\end{tabular}

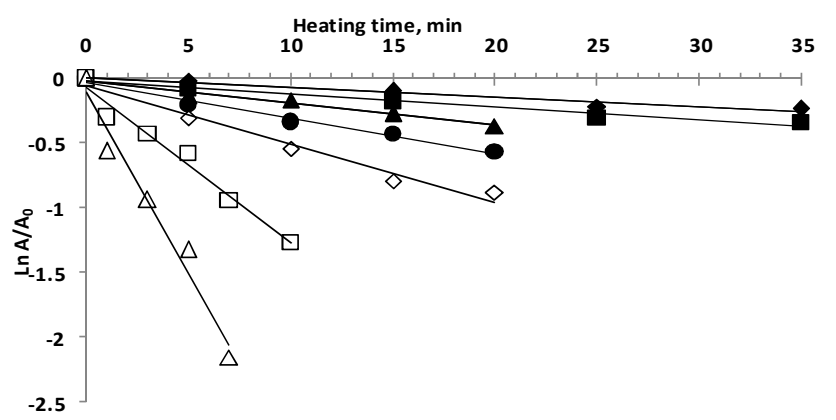

Fig. 1. First-order thermal inactivation of PME crude extract in $20 \mathrm{mM}$ citrate buffer at different temperatures: $50^{\circ} \mathrm{C}(\bullet), 55$ ${ }^{\circ} \mathrm{C}(\boldsymbol{\bullet}), 60^{\circ} \mathrm{C}(\boldsymbol{\Delta}), 65(\bullet), 70^{\circ} \mathrm{C}(\diamond), 75^{\circ} \mathrm{C}(\square), 80^{\circ} \mathrm{C}(\Delta)$ ( $A$ is the enzyme activity concentration at time $\mathrm{t}, A_{0}$ the initial enzyme activity)

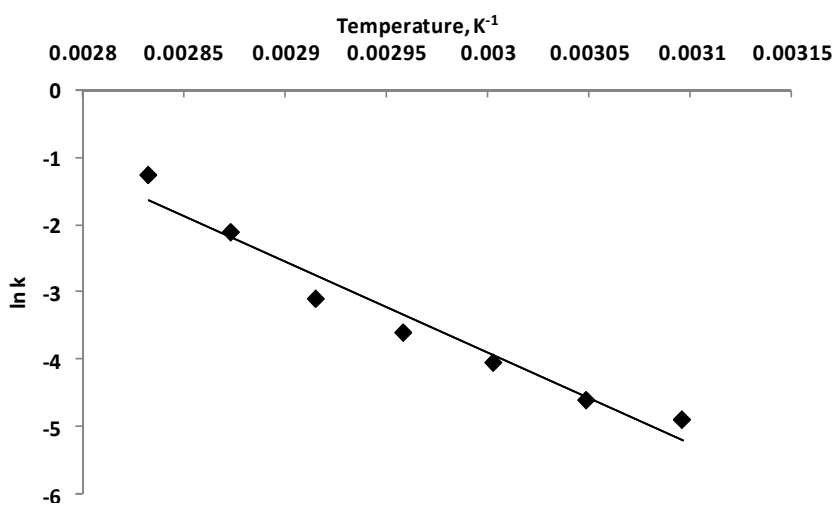

Fig. 2. Arrhenius plot for the thermal inactivation of PME crude extract in $20 \mathrm{mM}$ citrate buffer at $\mathrm{pH} 7.0$

Inactivation rate constant $(k)$ and decimal reduction time $(D)$ values, estimated using linear regression analysis of $\ln \left(A / A_{0}\right)$ versus $t$, were reported in Table 1 . As expected, the inactivation rate constant increased and $D$-values decreased with increasing temperature. The $k$ and $D$ values at $65^{\circ} \mathrm{C}$ were $0.027 \pm 0.004$ $\min ^{-1}$ and $84.98 \pm 3.30 \mathrm{~min}$, whereas the corresponding values estimated at $80^{\circ} \mathrm{C}$ were $0.28 \pm 0.19 \mathrm{~min}^{-1}$ and $8.25 \pm 1.09 \mathrm{~min}$. The obtained data suggested that pear PME is significantly heat stable when compared with the corresponding enzyme from other fruits and vegetables. The inactivation rate constants for purified PME from Navel oranges at $65^{\circ} \mathrm{C}$ were $0.889,1.536$, 0.288 and $0.234 \mathrm{~min}^{-1}$ in deionized water and citric buffer of $\mathrm{pH}$ 3.2, 3.7 and 4.2 (Van Den Broeck et al, 1999).Ly-Nguyen et al. (1999) suggested an inactivation rate constant value of 0.009 


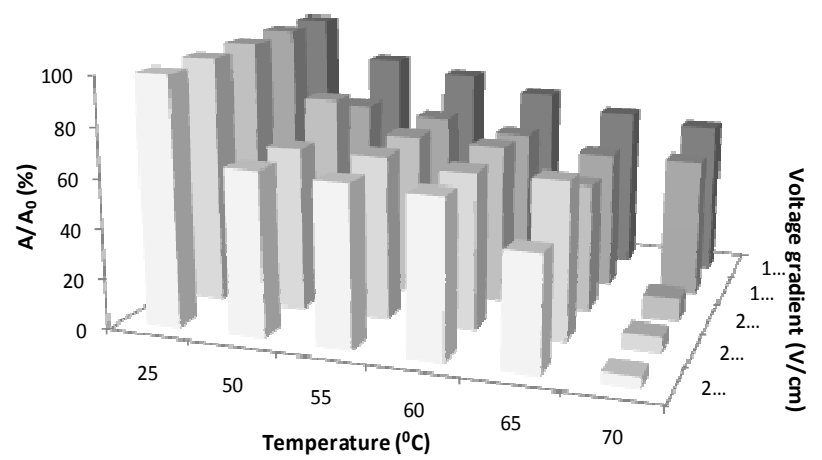

Fig. 3. The relative activity of PME crude extract after ohmic treatment at different temperatures and voltage gradient

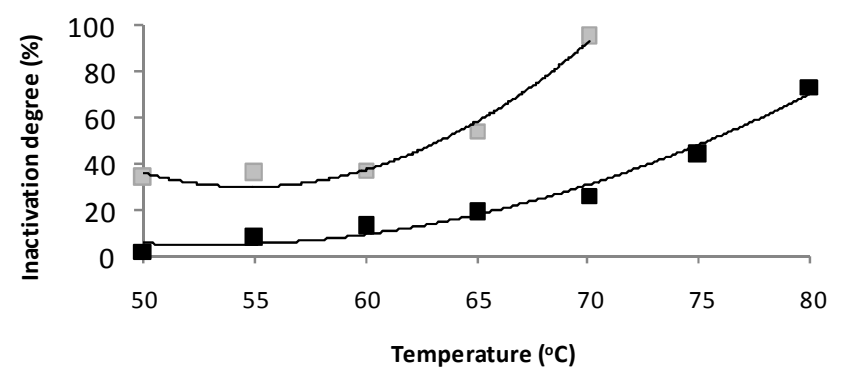

- Crude extract $\square$ Pear Puree

Fig. 4. Inactivation of PME crude extract and PME in pear purée by isothermal treatment for $5 \mathrm{~min}$ (black) and ohmic treatment at 25 $\mathrm{V} / \mathrm{cm}$ for $3 \mathrm{~min}$ (grey)

Table 2. Color measurements (CIELAB coordinates) of the pear purées before and after ohmic treatment

\begin{tabular}{lcc}
\hline Parameter & untreated & treated \\
\hline $\mathrm{L}^{*}$ & $44.30 \pm 1.11^{*}$ & $40.06 \pm 0.99$ \\
$\mathrm{a}^{*}$ & $-1.13 \pm 0.01$ & $-1.52 \pm 0.20$ \\
$\mathrm{~b}^{*}$ & $13.02 \pm 1.20$ & $13.44 \pm 1.22$ \\
$\mathrm{BI}(\%)$ & $32.5 \pm 0.56$ & $37.3 \pm 1.30$ \\
\hline standard errors & &
\end{tabular}

$\min ^{-1}$ and a $D$-value of $256.4 \mathrm{~min}$ at $65^{\circ} \mathrm{C}$ for banana PME. Espachs-Barroso et al. (2006) reported $k$ value of $0.0161 \pm$ $0.0013 \mathrm{~min}^{-1}$ at $66^{\circ} \mathrm{C}$ and $0.549 \pm 0.024 \mathrm{~min}^{-1}$ at $75{ }^{\circ} \mathrm{C}$ for purified banana PME.

The $z$-value for pear PME inactivation in citrate buffer was $19.23 \pm 1.23^{\circ} \mathrm{C}$, significantly higher than those reported in the literature. Duvetter $e t$ al. (2005) suggested a $z$-value of $5.70 \pm$ $0.09^{\circ} \mathrm{C}$ for PME from Aspergillus aculeatus.

The temperature dependence of inactivation rate constants in the temperature range studied could be adequately described by the Arrhenius equation (Fig. 2). The activation energy was $79.93 \pm 7.13$ and $158.06 \pm 14.99 \mathrm{~kJ} \cdot \mathrm{mol}^{-1}$ in the temperature range of $50-65{ }^{\circ} \mathrm{C}$ and respectively $65-80{ }^{\circ} \mathrm{C}$, suggesting the presence of two isoenzymes with different thermostability. These values were significantly lower than values reported in the literature: $289.2 \mathrm{~kJ} \cdot \mathrm{mol}^{-1}$ for carrots PME, $257.9 \mathrm{~kJ} \cdot \mathrm{mol}^{-1}$ for papaya pulp PME (Massaguer et al., 1994), $379.4 \mathrm{~kJ} \cdot \mathrm{mol}^{-1}$ for banana PME (Ly-Nguyen et al., 2002), 301.4-350.5 kJ.mol ${ }^{-1}$ for commercial orange PME (Van Den Broeck et al., 1999). Moreover, Van Den Broeck et al. (1999) suggested $E_{a}$ values ranging from 404.9 to $292.6 \mathrm{~kJ} \cdot \mathrm{mol}^{-1}$ for orange $\mathrm{PME}$ at $\mathrm{pH}$ ranging from 3.2 to 4.2. The current results indicated that the pear PME is more temperature stable and the $k$ values less sensitive to thermal treatment.

\section{Ohmic inactivation kinetics of PME from pear purée}

PME inactivation by ohmic treatment was performed at different voltage intensity, ranging from $15 \mathrm{~V} \cdot \mathrm{cm}^{-1}$ to $25 \mathrm{~V} \cdot \mathrm{cm}^{-1}$. The time required for pear purée samples to reach the desired temperature at different voltage intensities are shown in Table 2. It can be seen that the coming-up time increases with temperature and decreases with increasing intensity voltage. Therefore, the time required to heat the pear puré from 50 to $70^{\circ} \mathrm{C}$ at $15 \mathrm{~V} \cdot \mathrm{cm}^{-1}$ was 3 and 5.5 times longer than at 22.5 and 25 $\mathrm{V} \cdot \mathrm{cm}^{-1}$, respectively. The activity values were expressed as relative to the enzyme activity in the raw sample $\left(A_{0}\right)$. After a treatment at $15 \mathrm{~V} \cdot \mathrm{cm}^{-1}$ and $50^{\circ} \mathrm{C}$, approximately $84 \%$ of the initial activity was retained, whereas only $4.8 \%$ of the activity remained after applying a treatment at $25 \mathrm{~V} \cdot \mathrm{cm}^{-1}$ and $70{ }^{\circ} \mathrm{C}$. Leizerson et al. (2005) reported also a reduction of $90-98 \%$ in pectin esterase activity in orange juices during ohmic treatment. The relative activity of PME after ohmic treatments was presented in Fig. 3. It can be seen that the impact of ohmic treatment on PME activity increased by applying higher temperatures. Giner et al. (2005) suggested that any increase of electric field would yield considerable reduction in pectin esterase activity.

The thermal stability of PME in pear purée showed differences to the heat treatment on crude extract, probably due to the different behavior at various $\mathrm{pH}$ and medium composition. Therefore, PME was more sensitive to ohmic treatment at acidic $\mathrm{pH}$, achieving a maximum inactivation of approximately $96 \%$ at $25 \mathrm{~V} \cdot \mathrm{cm}^{-1}$ and $70{ }^{\circ} \mathrm{C}$, whereas a heat treatment at $70{ }^{\circ} \mathrm{C}$ for 3 minutes at neutral pH caused a $27 \%$ decrease in enzyme activity (Fig. 4).

\section{Color and reducing sugars}

The ohmic induced changes in color were monitored by lightness $\left(L^{*}\right)$, redness $\left(a^{*}\right.$, yellowness $\left(b^{*}\right)$, color difference $(\Delta \mathrm{E})$ and browning index (BI) (Table 3$)$.

An increase in temperature due to the ohmic treatment caused a darkening of the pear purée, which was reflected in the degree of lightness. This means that fresh pear purée was more susceptible to enzymatic browning than ohmic treated samples. When ohmic treatment was applied, $a^{*}$ values decreased, whereas $b^{*}$ values increased, indicating a loss in "greenness" and an increase in "yellowness". The corresponding value of color difference $(\Delta \mathrm{E})$ was calculated at $3.27 \pm 0.25$. (Moreno et al., 2013) and suggested also a small difference in $\Delta E$ for the fresh apple (cv. Granny Smith) during ohmic heating/osmotic dehydration treatments.

As expected, ohmic-treated pear purée browns during processing compared to fresh purée. The $\mathrm{BI}$ increased from $55.05 \%$ in fresh purée to $59.42 \%$ in the treated samples. The decrease in lightness of ohmic-heated purée correlated with the increase in their browning. Leizerson et al. (2005) also reported an increase in browning index and a decrease in lightness in orange juices during ohmic treatment.

Hexoses (fructose and glucose) are directly involved in browning reactions as well as sucrose, which can hydrolyze into glucose and fructose during thermal treatments. The ohmic treatment did not have a significant influence on the 
236

Table 3. Number of yeasts and molds per gram sample pear purée

\begin{tabular}{lcc}
\hline \multirow{2}{*}{ Voltage gradient, $\mathrm{V} \cdot \mathrm{cm}^{-1}$} & \multicolumn{2}{c}{$\mathrm{CFU} \cdot \mathrm{g}^{-1}$ purée } \\
\cline { 2 - 3 } & After treatment & After 7 days at $4{ }^{\circ} \mathrm{C}$ \\
\hline 0 & $2.66 \times 10^{3}$ & $9.85 \times 10^{2}$ \\
15 & $2.615 \times 10^{3}$ & $4.64 \times 10^{2}$ \\
17.5 & $2.34 \times 10^{3}$ & $2.14 \times 10^{2}$ \\
20 & 0 & 0 \\
22 & 0 & 0 \\
25 & 0 & 0 \\
\hline
\end{tabular}

concentration of reducing sugars and the variation among data was within the standard error $(4.54 \pm 1.36 \%$ in fresh puréeand $4.68 \pm 0.32 \%$ in ohmic treated samples). However, the steady concentration of sugars during thermal treatment showed that they did not react with amino-acids and consequently did not influence browning. The 3\% increase in reducing sugar content may be due to water evaporation at high temperature. Damasceno et al. (2008) suggested a thermally-induced reduction less than $4 \%$ compared to the initial sugar concentration for cashew apple juice.

\section{Totalphenolic content}

The initial phenolic content of fresh pear was $398 \pm 28 \mathrm{mg}$ GAE $100 \mathrm{~g}^{-1}$ FM. A reduction of $59 \%$ in comparison with fresh pear purée in the total phenolic content was observed in treated samples (233 $\pm 58 \mathrm{mg}$ GAE $\left.100 \mathrm{~g}^{-1} \mathrm{FM}\right)$. Mrad et al. (2012) suggested a total phenolic content of $254.90 \pm 9.10 \mathrm{mg}$ GAE $100 \mathrm{~g}^{-1} \mathrm{DM}$ in fresh pear, whereas a significant decrease was observed by these authors during drying at $70^{\circ} \mathrm{C}$. The observed variations are related to the chemical and enzymatic oxidation reactions which occur during purée preparation and heating.

In pear and other fruit, phenolics are relatively more concentrated in the skin compared to the flesh. Damages of the membrane ultrastructure caused by blending permit rapid oxidation of the phenolics compounds.

The content in anthocyanin and other polyphenolics compounds may vary due to many others factors than just heat treatment or polyphenoloxidase activity, including the presence of air. Also, it has been suggested that the decrease in phenolic content can also be attributed to the binding of polyphenols with other compounds (such as proteins) or to the alterations in the chemical structure of polyphenols (Martín-Cabrejas et al., 2009; Qu et al., 2010).

\section{Therheological behavior of pearpurées}

The importance of rheological properties of fruits and vegetables are given by the human perception of product quality, the causes and extent of damage during harvesting, transport and storage and the physiological changes, being important during growth, maturation, ripening and storage after harvest (Rao et al., 1992).

In order to evaluate the rheological behavior of pear purées, the shear stress $(\tau)$ and apparent viscosity $(\eta)$ against shear rate $(\gamma)$ were depicted as seen in Fig. 5. From these figures it can be evidenced that the variation was exponential and therefore the purée were non-Newtonian pseudo-plastic fluids. The shear stress increased with the shear rate (Fig. 5). This behavior could be explained by the structural breakdown of the molecules due to the hydrodynamic forces generated and the increased alignment of the constituent molecules (Izidoro et al., 2008).
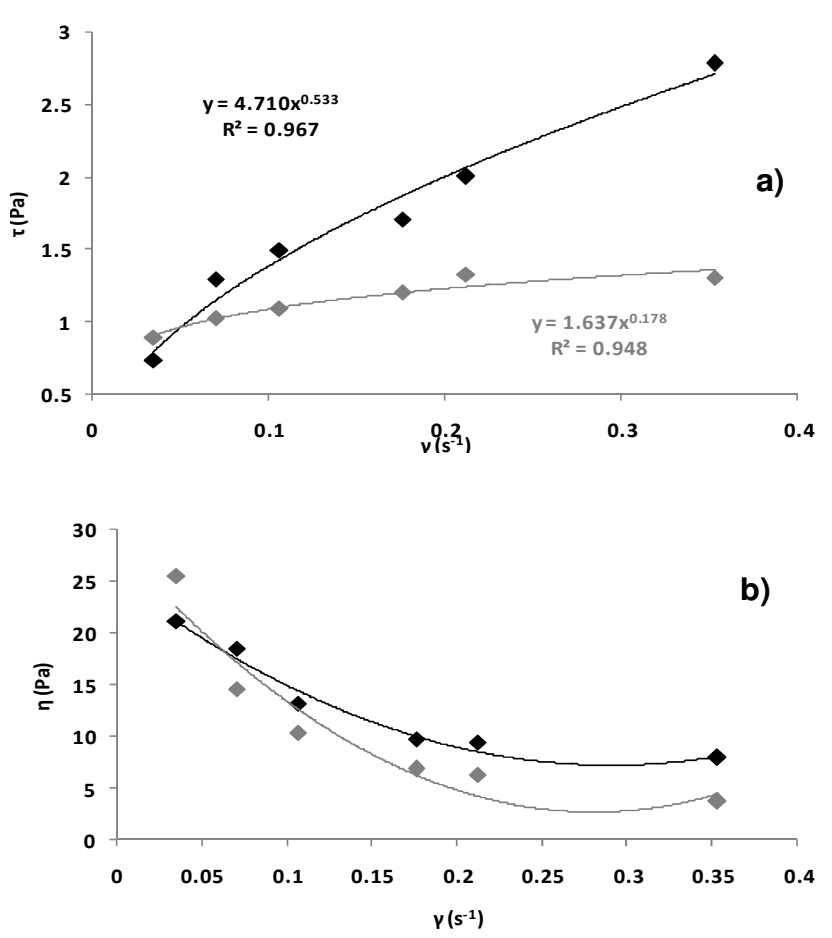

Fig. 5. Variations of the rheological parameters for the fresh pear purée (black) and ohmic treated (grey) pear purée at 25 $\mathrm{V} / \mathrm{cm}$; a) Shear stress dependence on shear rate; b) Dynamic viscosity dependence on shear rate

The minimum values for the shear stress ( $0.73 \mathrm{~Pa}$ for the raw pear purée and $0.89 \mathrm{~Pa}$ for the ohmic heated one) were corresponding to the shear rate values of $0.035 \mathrm{~s}^{-1}$. When shear rate values increased from 0.035 to $0.353 \mathrm{~s}^{-1}$, the dynamic viscosities decreased from 21.1 to 7.9 Pa.s for the fresh purée and from 25.5 Pas to $3.68 \mathrm{~Pa}$.s for the ohmic treated one. These differences in dynamic viscosities values were probably due to the water evaporation during thermal treatment.

Fitting the Power law model to the flow curves resulted in $n$ values less than one (Fig. 5) which indicated pseudo-plastic flow behavior. Considering the $n$ values ( 0.53 for fresh purée and 0.17 for the treated one), it seemed that ohmic treatment significantly altered the size of particles. Many solutions exhibit the value of $n$ in the range of 0.3-0.7 depending upon the concentration and molecular weight of the polymers. Smaller values of $n(0.1-0.15)$ are characteristic for finer particle suspensions (Chhabra et al., 2008). It has been reported that fruit purées behave as nonNewtonian fluid as a result of complex interactions among soluble sugars, pectic substances and suspended solids (Ahmed $e t$ al., 2004). The current results were in good agreement with data from literature, which enclose the fruit purées in pseudo-plastic fluids category (Balestra et al., 2011; Steffe, 1996).

\section{Microflora}

Table 3 summarizes the molds and yeasts content in control and treated pears purée after processing and during one week of storage at $4^{\circ} \mathrm{C}$. It can be seen that the amount of CFUs in both cases was higher in the control, whereas the ohmic treatment at voltage intensities higher than $17.5 \mathrm{~V} \cdot \mathrm{cm}^{-1}$ caused a complete inactivation of microorganisms. In the case of storage, the amount of CFUs decreased in positive samples with 1 logduring storage. 


\section{Conclusions}

Changes in pectin methylesterase activity during conventional thermal treatment of crude extract were described by first order kinetics, with activation energy of $79.93 \pm 7.13$ and $158.06 \pm$ $14.99 \mathrm{~kJ} \cdot \mathrm{mol}^{-1}$ in the temperature range of $50-65^{\circ} \mathrm{C}$ and respectively $65-80^{\circ} \mathrm{C}$. In pear purée, PME was more sensitive to ohmic treatment, achieving a maximum inactivation of approximately $96 \%$ at $25 \mathrm{~V} \cdot \mathrm{cm}^{-1}$ and $70^{\circ} \mathrm{C}$. No significant changes were observed in nutritional (total polyphenols, reducing sugars), sensorial (color) and rheological attributes. The rheological experiments evidenced that pear purées had a complex nonNewtonian pseudo-plastic behavior. Furthermore, the microbial counts was zero in ohmic treated purées at voltage intensities higher that $17.5 \mathrm{~V} \cdot \mathrm{cm}^{-1}$, whereas microbial counts decreased with 1 log during one week of storage at $4{ }^{\circ} \mathrm{C}$ for the positive samples. Based on the results obtained, ohmic treatment can be used in food processing and bioengineering for the inactivation of microorganisms and quality-degrading enzymes, as well as the retention of health-related compounds and the extension of shelflife.

\section{Acknowledgements}

The work of Oana-Viorela Nistor was supported by Project SOP HRD - TOP ACADEMIC 76822. The morphological analyses were supported by the Faculty of Chemistry, Alexandru Iona Cuza University, Iași, România. Bioaliment platform (www.bioaliment.ugal.ro) is acknowledged for providing technical support.

\section{References}

Ahmed J, Shivare US, Singh P (2004). Colour kinetics and rheology of coriander leaf purée and storage characteristics of the paste. Food Chem 84:605-611.

Balestra F, Coccia E, Marsilioa G, Dalla Rosaa M (2011). Physicochemical and rheological changes of fruit purées during storage. Procedia Food Sci 1:576-582.

Barrett DM, Gonzalez C (1994). Activity of softening enzymes during cherry maturation. J Food Sci 59:574-577.

Budini R, Tonelli D, Girotti S (1980). Analysis of total phenols using the Prussian Blue method.J Agric Food Chem 28:1236-1238.

Chen CS, Shaw PE, Parish ME (1993). Orange and tangerine juices. In: Nagy S, Chen CS, Shaw PE (Eds), Fruit juice processing technology, Auburndale, USA: Ag science, pp 110-165.

Chhabra RP, Richardson JF (2008). Non-Newtonian flow and applied rheology (Second edition). Butterworth-Heinemann, Oxford.

Damasceno LF, Fernandes FAN, Magalhães MAM, Brito ES (2008). Non-enzymatic browning in clarified cashew apple juice during thermal treatment: Kinetics and process control. Food Chem 106:172-179.

Duvetter T, Van Loey A, Smout C, Verlent I, Ly-Nguyen B, Hendrickx M (2005). Aspergillus aculeatus pectin methylesterase: study of the inactivation by temperature and pressure and the inhibition by pectin methylesterase inhibitor. Enz Microb Techn 36:385-390.
Elez-Martínez P, Suárez-Recio M, Martín-Belloso O (2007). Modeling the reduction of pectin methyl esterase activity in orange juice by high intensity pulsed electric fields. J Food Eng 78:184-193.

Espachs-Barroso A, Van Loey AM, Hendrickx M, Martín-Belloso O (2006). Inactivation of plant pectin methylesterase by thermal or high intensity pulsed electric field treatments. Inn Food Sci Emerg Techn 7:40-48.

Giner J, Gimeno V, Barbosa-Cánovas GV, Martín O (2001). Effects of pulsed electric field processing on apple and pear polyphenoloxidases. J Food Sci Tech 7:339-345.

Giner J, Bailo E, Gimeno V, Martin-Belloso O (2005). Models in a Bayesian framework for inactivation of pectin-esterase in a commercial enzyme formulation by pulsed electric fields. Eur Food Res Techn 221:255-64.

Hendrix CM, Redd JB (1995). Chemistry and technology of citrus juices and by-products. In: Ashurst PR (Ed), Production and packaging of non-carbonated fruit juices and fruit beverages, New York, USA: Chapman \& Hall, pp 53-87.

Hutchings JB (1994). Food coloring and appearance. Glasgow, UK: Blackie Academic\& Professional, pp 199-237.

Izidoro DR, Scheer AP, Sierakowski MR, Haminiuk WI (2008). Influence of green banana pulp on the rheological behavior and chemical characteristics of emulsions (mayonnaises). LWT- Food Sci Techn 41:1018-1028.

Jayani RS, Saxena S, Gupta R (2005). Microbial pectinolytic enzymes: a review. Proc Biochem 40:2931-2934.

Leizerson S, Shimoni E (2005). Effect of ultrahigh-temperature continuous ohmic heating treatment on fresh orange juice. J Agric Food Chem 53:3519-3524.

Ly-Nguyen B, Van Loey A, Fachin D, Verlent I, Indrawati O, Hendrickx M (2002). Purification, characterization, thermal, and high-pressure inactivation of pectin methylesterase from bananas (cv Cavendish). Biotech Bioeng 78:683-691.

Ly-Nguyen B, Van Loey A, Fachin D, Verlent I, Indrawati O, Hendrickx M (2002). Partial purification, characterization, thermal and high pressure inactivation of pectin methylesterase from carrots (Daucus carota L.). J Agric Food Chem 50:54375444.

Massaguer PR, Magalhaes MA, Tosello RM (1994). Thermal inactivation of pectinesterase in papaya pulp ( $\mathrm{pH}$ 3.8). In: Yano T., Matsumoto R, Nakamura K (Eds), Developments in Food Engineering, Blackie: London, UK, pp 495-497.

Miller GL (1959). Use of dinitrosalicylic acid reagent for determination of reducing sugar. Anal Chem 31:426-428.

Martín-Cabrejas MA, Aguilera Y, Pedrosa M, Cuadrado C, Hernández T, Díaz S, Esteban RM (2009). The impact of dehydration process on antinutrients and protein digestibility of some legume flours. Food Chem 114:1063-1068.

Moreno J, Simpson R, Pizarro N, Pavez C, Dorvil F, Petzold G, Bugueño $G$ (2013). Influence of ohmic heating/osmotic dehydration treatments on polyphenoloxidase inactivation, physical properties and microbial stability of apples (cv. Granny Smith). Inn Food Sci Emerg Techn. 20:198-207. 
238

Mrad ND, Boudhrioua N, Kechaou N, Courtois F, Bonazzi C (2012). Influence of air drying temperature on kinetics, physicochemical properties, total phenolic content and ascorbic acid of pears. Food Bioprod Proc 90:433-441.

Qu W, Pan Z, Ma H (2010). Extraction modeling and activities of antioxidants from pomegranate marc. J Food Eng 99:16-23.

Rao MA, Steff JF (1992).Viscoelastic properties of foods. London: Elsevier Applied Science.

Reznick D (1996). Ohmic heating of fluid foods. Food Tech 50:250251.

Sastry SK, Li Q (1996). Modeling the ohmic heating of foods. Food Tech 50:246-248.

Sastry SK, Barach JT (2000). Ohmic and inductive heating. J Food Sci 65:42-46.
Steffe JF (1996). Rheological methods in food process engineering (second edition). Freeman Press, East Lansing, USA.

Van Den Broeck I, Ludikhuyze LR, Van Loey AM, Weemaes CA, Hendrickx M (1999). Thermal and combined pressuretemperature inactivation of orange pectinesterase: influence of $\mathrm{pH}$ and additives. J Agric Food Chem 47:2950-2958.

Van Den Broeck I, Ludikhuyze LR, Weemaes CA, Van Loey AM, Hendrickx M (1999). Thermal inactivation kinetics of pectinarase extracted from oranges. J Food Proc Pres 23:391-406.

Vandevenne E (2011). Investigating the in situ localization of pectin methyl-esterase and its inhibitor: Development of an immunological toolbox. $\mathrm{PhD}$ thesis. Katholieke Universiteit Leuven, Groep Wetenschap \& Technologie, Arenberg Doctoraatsschool, W. de Croylaan 6, 3001 Heverlee, België. 